Annals of Warsaw University of Life Sciences - SGGW

Land Reclamation No 49 (4), 2017: 255-267

(Ann. Warsaw Univ. of Life Sci. - SGGW, Land Reclam. 49 (4), 2017)

\title{
Identification of vegetation parameters for compound channel discharge as inverse problem
}

\author{
ADAM KICZKO $^{1}$, ADAM KOZIOŁ $^{1}$, JANUSZ KUBRAK $^{1}$, \\ MARCIN KRUKOWSKI ${ }^{1}$, ELŻBIETA KUBRAK ${ }^{2}$, ANDRZEJ BRANDYK ${ }^{2}$ \\ ${ }^{1}$ Faculty of Civil and Environmental Engineering \\ ${ }^{2}$ Laboratory - Water Centre \\ Warsaw University of Life Science - SGGW
}

\begin{abstract}
Identification of vegetation parameters for compound channel discharge as inverse problem. In recent years many sophisticated models for discharge capacity of compound channels with vegetation have been developed. Despite the mature state of knowledge in this field, in a practice the simplest methods prevail and most of hydraulic models are based on the Manning formula. One of the reasons is that more complex methods require detailed characteristics on vegetation. The present study demonstrates that this issue can be solved by treating all such necessary variables as parameters to be identified in a sense of an inverse problem, using techniques of optimization. With a flume experiment as a case study, four models of a uniform flow were identified: Pasche, Mertens as complex methods, divided channel method (DCM) with Manning and Darcy-Weisbach equations as techniques used in a practice. Results showed that parameters for all methods can be found on the basis of minimization of model residuals, with the restriction that because of the larger number of parameters in complex methods, more observations are required. Methods of Pasche and Mertens with identified parameters provided a much better explanation of water depths than the Manning or Darcy-Weisbach based on the DCM. It is surprising that significant discrepancies between identified parameters and their real measured values were recorded. Even more, an almost perfect fit was obtained for different parameter sets.
\end{abstract}

Key words: channel discharge capacity, compound channel, Pasche method, Mertens method

\section{INTRODUCTION}

Modeling of an open-channel capacity is one of the fundamental problems in hydraulics. Natural channels like rivers are usually characterized by a compound cross section. It consists of different flow zones, among which a main channel and floodplains can be distinguished. The open-channel flow is by its nature three-dimensional but because of practical purposes usually a one-dimensional approximation is used. Such a simplification requires a parameterization of these flow terms which do not fulfill this assumption.

One of these terms is the flow resistance of vegetation. The process is very complex, involving plant and stream interactions and various studies have showed its importance for the channel discharge capacity. As an example, Fread (1989) demonstrated strong dependence of the flow resistance in vegetated channels on flow rate for various rivers. Kiczko et al. (2013) and Romanowicz and Kiczko 
(2016) considered this dependency as a main source of the uncertainty in the flood mapping.

Therefore, many researchers investigated the methods that would provide an explanation of the flow through the vegetated sections of the compound channel. The well-known method was developed by Pasche (Pasche and Rouvé 1985), which is especially popular in Germany, were it is used in channel design assignments. The methodology is based on the detailed physical description of the flow in the vegetated areas of the channel, explaining the interactions between streams in vegetated floodplains and the main channel. The model is however limited to unsubmerged vegetation, which geometric properties can be approximated with rigid cylinders. In the original form the Pasche method consists of several implicit equations making it hard to implement and to improve its practical applicability, Mertens (1989) proposed a simplified version.

Recent efforts in the modeling of the compound channels aim at developing methods for submerged and nonstiff vegetation (Västilä et al. 2013, Jalonen and Järvelä 2014, Västilä and Järvelä 2017). It becomes possible to establish a link between plant properties like spacing, leaf coverage and a drag of the vegetated zone. An interesting approach could be a combination of the detailed model of a compound cross section, given with Shiono and Knight (1991) method with an additional term for the vegetation drag (Kozioł et al. 2016).

Today the methodology for the discharge capacity of the vegetated channels is well developed. It might be, however, surprising that advanced methods, like those aforementioned, are rarely used in practice. In most of practical applications the hydraulic resistance is modeled on the basis of the Manning or Darcy-Weisbach formula. The vegetated zones are being characterized using usually a single value of a roughness coefficient, respectively Manning coefficient $(n)$ or the roughness height $(k)$. Case studies which account for roughness and water stage dependency are rather exceptional, even that most popular hydraulic models, like MIKE 11, are able to include it.

Two reasons could be pointed out, which explain such a conservative approach of flow modelers. First of all, it has to be noticed, that all complex methods for flow in vegetated channels require detailed data on vegetation properties, like density, spacing, shape or species, leaf characteristic and so on. In a practical case, where the model is developed for river reaches long for tens of kilometers such information is simply missing. If there is no data on vegetation characteristics, the use of a single value of the roughness coefficient $n$ or $k$ for the flow area seems to be a reasonable solution. The second, also an important argument for simpler parametrization is that roughness parameters are being often used beyond their physical interpretation, as "catch all parameters". Such parameters explain other components of the real system better than physical resistance. Higher or lower values of the Manning coefficient could be used for river reaches which geometric complexity is not well reflected by geometric data, because of insufficient spacing of cross sections. The extreme example is the use of very high values of roughness for step-pool channels to describe mul- 
tiple sub-supercritical flow transitions (Reid and Hickin 2008).

This study deals with the first of aforementioned arguments against specialized methods for flow in vegetated channels in practical applications. It appears that detailed data on vegetation is not necessary to apply these methods. The conclusion is supported by numerical experiments performed for the flume data, where it was possible to apply Pasche and Mertens methods without prior knowledge on vegetation characteristics. The necessary plant parameters were obtained on the basis of an inverse problem, with values being established by minimizing the difference between computed and calculated water level. This required to investigate the problem of ill-posedness of parameter identification task that arises when number of observation data points is insufficient to find unique values of parameters. Conditioning the parameter identification on water level instead of discharges was intended to make the problem more similar to practical cases, like flood assessments, where a model outcome is usually the water level.

The accuracy of Pasche and Mertens models, with respect to a number observation data points used in the parameter identification, is compared with Manning and Darcy-Weisbach formulae used along with divided channel method - DCM (Chow 1959).

\section{MATERIAL AND METHODS}

The study accounts for water levels calculations for the compound channel with vegetated floodplains. The channel discharge capacity was modeled using four methods: Pasche, Mertens, DCM with Manning and Darcy-Weisbach formulae. As flume data was used, obtained for controlled flow conditions, it was possible to apply these methods in a simple steady and uniform model of the compound channel.

\section{Pasche and Mertens methods}

Pasche (1985) method for the discharge capacity of the compound cross section with vegetation was derived for the steady flow conditions. Like in the DCM, the flow field is divided into regions dominated by bottom, vegetation roughness - main channel and floodplains respectively, for the cross section of a regular compound channel. Additionally, the transition region, between these two is also distinguished. The interaction between vegetated and unvegetated regions are modeled using an imaginary rough wall. For each flow zone the resistance is described in terms of Darcy-Weisbach equation.

The method consists of a set of semi-empirical equations for Darcy-Weisbach friction coefficients for each zone and an imaginary wall at the interface between vegetation and bottom dominant roughness. Moreover, the width of the transition region, usually between the main channel and floodplain streams has to be estimated. The methodology provides an explanation of the width of such a region in the vegetated area (floodplain), affected by a stream of a higher velocity in the unvegetated channel (main channel). There is no, however, a general expression for the width of the interaction zone in the main channel and its span has to established for each case. 
The stream velocity and roughness coefficients are interrelated and formulae in Pasche method have an implicit form that requires iterative methods to solve. As a result of it the Pasche method is computationally demanding. To improve its applicability and numerical efficiency the method was simplified by Mertens (1989). In this approach, the general concept is maintained, however less significant coefficients, were fixed here, that allowed Mertens to reduce a number of terms requiring iterative solving.

In Pasche and Mertens methods, the roughness of the vegetated cross section is characterized using plant properties, surface roughness and the extent of the interaction zone in the main channel. For the analyzed compound cross section with two symmetric floodplains, the following values were necessary: $a_{x}, a_{y}$ - longitudinal and horizontal steam spacing; $d_{p}$ - steam averaged diameter; $k_{f}, k_{c}$ - roughness height of the floodplain and the main channel bed; $b_{I I I} / B_{c}-$ ratio of the interaction region width $\left(b_{I I I}\right)$ in the main channel to the main channel width $\left(B_{c}\right)$.

\section{Divided channel method with Manning and Darcy-Weisbach formulae}

The complex methods of Pasche or Mertens are being compared with the most widely used methodology of Manning formula with the divided channel method. In addition, the DCM with Darcy-Weisbach equation was also applied, as the alternative method in many hydraulic models.

In the DCM approach, the flow cross section is divided in flow zones of similar hydraulic conditions, like: the main channel and floodplain. The stream interactions between the zones of a significantly different mean velocity are reproduced with the rough imaginary wall, applied to a zone with a higher velocity, i.e. the main channel. In the present study, the roughness of the interface was the same as the roughness of the real walls next to the interface.

The analyzed channel was characterized using two values of the Manning coefficients $\left(n_{c}\right.$ and $\left.n_{f}\right)$ for the main channel and floodplains. In the case of Darcy-Weisbach formula, the values of the hydraulic roughness were used: $k_{f}$ and $k_{c}$.

\section{Parameter identification}

It was assumed that for the identification of model parameters only information on flow rates and water levels was available. All values, necessary to describe roughness, were considered as the model parameters, even if their true values were known in the experimental data. In this way, the values that characterize the physical properties of the channel, like surface roughness, vegetation physical properties, spacing, width (provided later with "hat" symbol) were treated in the same way as the Manning roughness coefficient for the whole flow section. Therefore, in Pasche and Mertens approaches it was necessary to identify six parameters $\left(\hat{a}_{x}, \hat{a}_{y}, \hat{d}_{p}, \hat{k}_{f}, \hat{k}_{c}\right.$ and $\left.\hat{b}_{I I I} / B_{c}\right)$, while in DCM just two $\left(\hat{n}_{c}, \hat{n}_{f}\right)$ for the Manning formula and two $\left(\hat{k}_{f}, \hat{k}_{c}\right)$ for the Darcy-Weisbach. The goal was to investigate if values being a strict physical description of the vegetated channel can be found as the solution to the inverse problem, as it is usually done for the Manning and Darcy-Weisbach approaches. 
To make the analysis similar to practical tasks, where usually the flow model is solved for the water levels, calculations were also performed with respect to their values. As the considered methods are defined for the channel discharge, water levels were calculated by minimization of the difference between the given and computed flow rate. The identification of parameters $\theta$ was done by minimizing the sum of model residuals for output water levels $\hat{H}$, with respect to $n$ observations $H$ :

$\theta=\arg \min \sum_{i=1}^{n}\left(\hat{H}_{l}-H_{i}\right)^{2}$

The minimization was done on the basis of the Monte Carlo sampling method (Niederreiter 1992). The number of simulation was obtained by errors and trials to ensure that the best solution was found. For DCM approaches 10,000 samples were used, while for Pasche and Mertens methods 40,000.

\section{Flume data}

The study was based on the flume data, previously exploit in various studies of the WULS-SGGW Hydraulic Department (Kozioł 2011, 2013; Kozioł et al. 2016). The model consisted of the straight 16-meter long channel with the compound trapezoidal cross section, which is 2.10 -meter wide (Fig. 1). In the analyzed experimental case, the main channel walls were made of smooth concrete with the estimated roughness height $k_{s}=5 \cdot 10^{-5} \mathrm{~m}$. Floodplains roughness was much higher with $k_{f}=1 \cdot 10^{-2} \mathrm{~m}$, modeled using a layer of terrazzo concrete of the

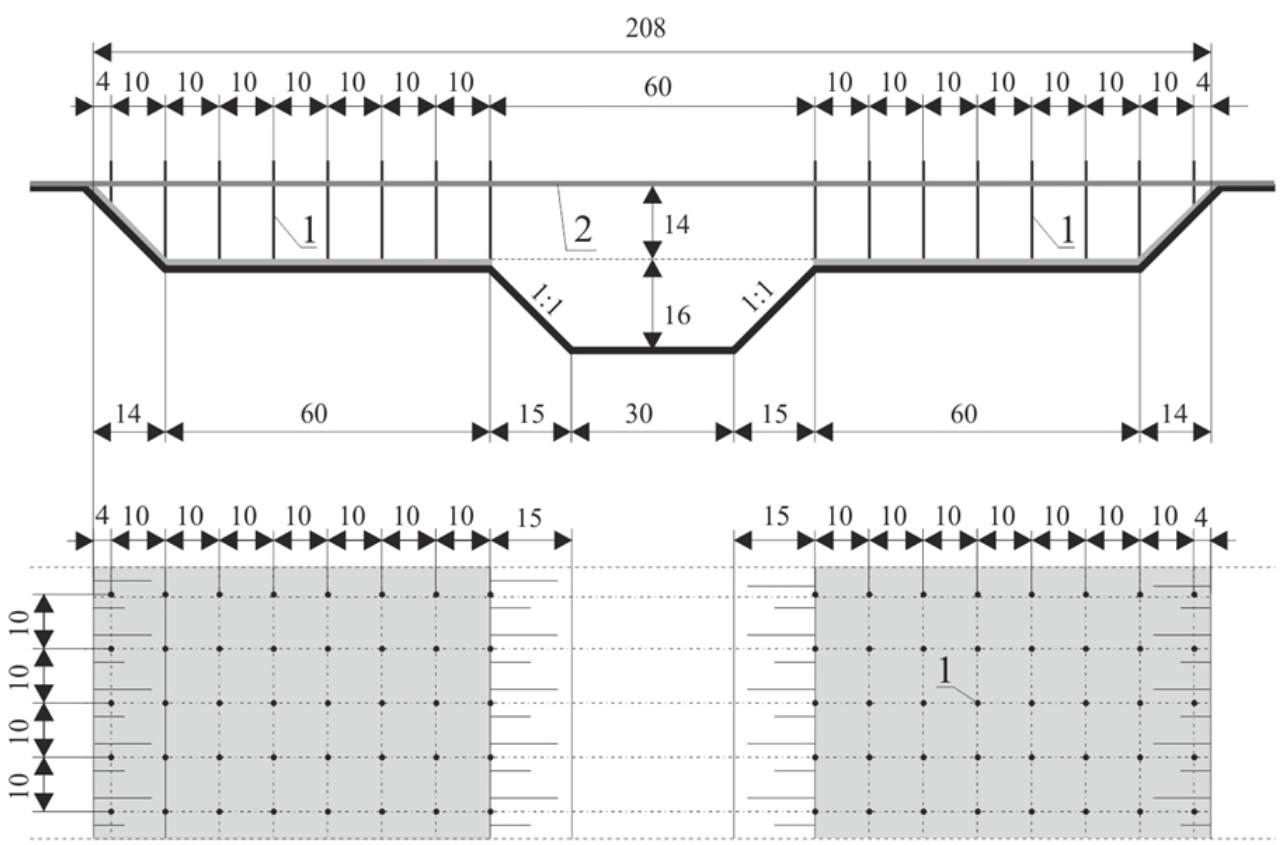

FIGURE 1. Laboratory channel cross section (dimensions in $\mathrm{cm}$ ); 1 - rigid cylinders simulating vegetation; 2 - wooden strips supporting vegetation (Kozioł 1999) 
grain size of $0.5-1 \mathrm{~cm}$ (Kozioł 2011). Vegetation was modeled with rigid cylinders of a diameter $d_{p}=0.008 \mathrm{~m}$ and spacing $a_{x}=a_{y}=0.1 \mathrm{~m}$.

Experiments were performed for steady and uniform flow conditions. Water surface was kept parallel to the bed using a weir localized at the flume outflow. Water discharge was measured using circular overfall and water levels were recorded in the middle of the channel. The data set used in the present experiment consisted of 10 discharge and water level observations within the range of: $0.037-0.060 \mathrm{~m}^{3} / \mathrm{s}$ and $0.2-0.3 \mathrm{~m}$, respectively.

\section{RESULTS AND DISCUSSION}

To address the research goal, model parameters were identified on the basis of Eq. 1 for a different number of observation points. Having the set of 10 observed values of a discharge and water level, parameters were identified for $n=1, \ldots, 10$. Here, however, it was necessary to face the problem of many possible combinations of observation points, that could be used in the task. For example, for 2 observations selected from the 10 element set, there is 45 possible combinations. As it is later discussed the choice of observation points is significant for the model's overall fit. Therefore, it was decided to analyze all possible combinations in the parameter identification. The total number of all possible combinations for $n=1, \ldots, 10$ is $2^{N}=1,024$.

The optimization problem, stated with Eq. 1 for all combinations of varying numbers of observations was solved using the Monte Carlo technique. This allowed simplifying the computations, as the random sampling of parameters was done only once and $2^{N}$ required solutions were obtained as these with the smallest sum of residuals for given $n$. For each method parameters were sampled with a pseudorandom number generator in presumed ranges (Table 1).

Figure 2 presents box-plots of an overall coefficient of determination $\left(R^{2}\right)$, calculated for all $N$ observations, for

TABLE 1. Parameter ranges for Monte Carlo sampling

\begin{tabular}{|l|c|c|c|c|}
\hline Method & Parameter & Lower band & Upper band & Unit \\
\hline \multirow{4}{*}{ Pasche and Mertens } & $\hat{a}_{x}, \hat{a}_{y}$ & 0.05 & 0.90 & $\mathrm{~m}$ \\
\cline { 2 - 5 } & $\hat{d}_{p}$ & 0.004 & 0.072 & $\mathrm{~m}$ \\
\cline { 2 - 5 } & $\hat{k}_{f}$ & 0.005 & 0.09 & $\mathrm{~m}$ \\
\cline { 2 - 5 } & $\hat{k}_{c}$ & 0.000025 & 0.000450 & $\mathrm{~m}$ \\
\cline { 2 - 5 } & $\hat{b}_{I I I} / B_{c}$ & 0.33 & 1 & - \\
\hline \multirow{3}{*}{ DCM with Manning formula } & $\hat{n}_{f}$ & 0.06 & 0.12 & $\mathrm{~m}^{-1 / 3} \cdot \mathrm{s}$ \\
\cline { 2 - 5 } & $\hat{n}_{c}$ & 0.012 & 0.12 & $\mathrm{~m}^{-1 / 3} \cdot \mathrm{s}$ \\
\hline \multirow{2}{*}{ DCM with Darcy-Weisbach formula } & $\hat{k}_{f}$ & 0.004 & 0.2 & $\mathrm{~m}$ \\
\cline { 2 - 5 } & $\hat{k}_{c}$ & 0.003 & 0.2 & $\mathrm{~m}$ \\
\hline
\end{tabular}


a

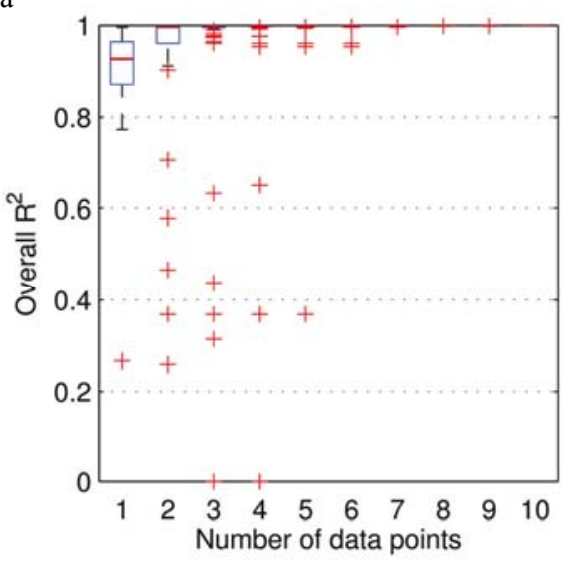

c

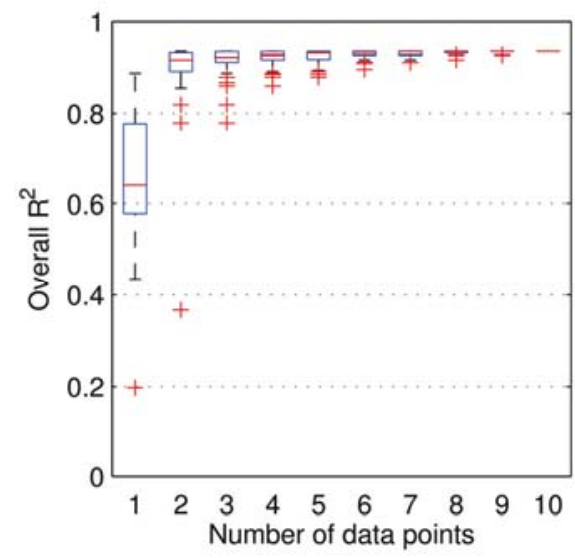

b

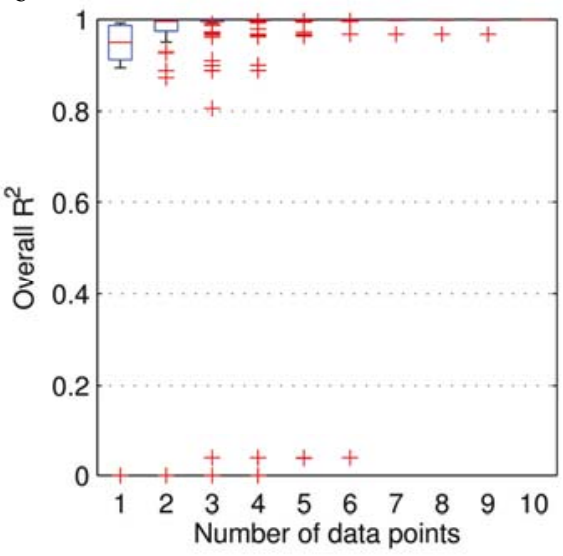

d

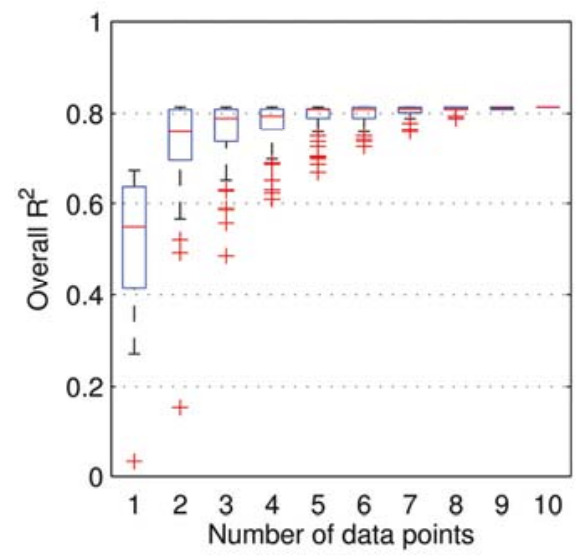

FIGURE 2. Distribution of determination coefficient $\left(R^{2}\right)$ in a respect of data points used in parameter identification; (a) Pasche method; (b) Mertens method; (c) DCM with Manning formula; (d) DCM with Darcy-Weisbach formula

identified models with respect to $n$. The variation of the $R^{2}$ results from different performance of models obtained for specific combination of observations. For low values of $n$ it shows the significance of the data used in parameters identification. Of course, it is unsurprising that two extreme observations could provide much more information on the functional dependency than several but clustered values.
The more important in Figure 2 is the analysis of the uniqueness in the identification problem. The plot reveals a clear dependency between the number of parameters and observation points used for identification. For all methods the spread of overall $R^{2}$ significantly decreases when a number of observations exceeds the number of parameters. For the DCM with the Manning and Darcy-Weisbach equation it can 
be observed for $n>2$, while for Pasche and Mertens methods $n>6$. The good explanation of the uniqueness problem provides Figure 3. It shows the discharge curve for the Manning based on the DCM, where parameters were identified using single point observation data: the lowest (Fig. 3a) and the highest (3b) flow rate. In both cases, the identification was successful, providing perfect fit to the data point used to estimate parameters. However, obtained models are miserable in reproducing other water levels.

The necessary number of data point to avoid the uniqueness of the parameter identification is clearly a significant drawback of the more complex methods. The required data set for the very simple calculations for a single cross section is three times bigger for Pasche and Mertens than DCMs. The undeniable advantage of the more complex methods is a much more accurate description of the process, with a sufficient number of observations. This can be seen in $R^{2}$ for $n>6$ in

a

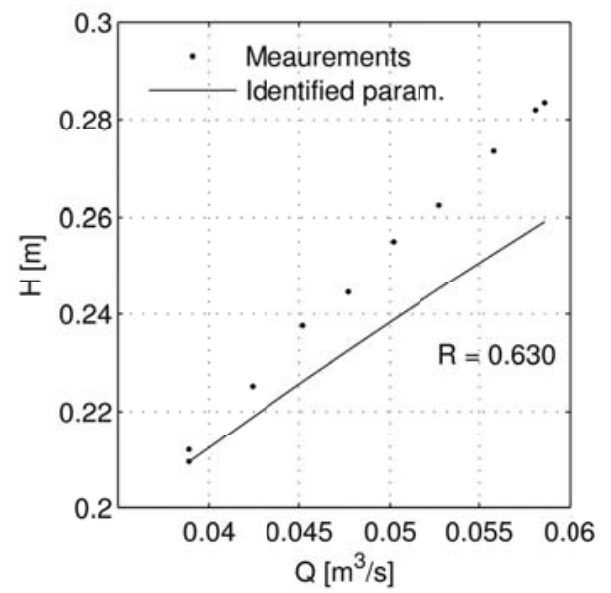

Figure 2 and discharge curves calculated for $50 \%$ and a full set of observations and, as shown in Figures 4 and 5, respectively. Figure 4 was obtained for models identified using $50 \%$ of an observation set. This simulates the common practical task, where a model is being conditioned for several past flood events and then used for events of a higher magnitude i.e. design flows. In the case of Pasche and Mertens methods, the extrapolated discharge curve almost perfectly follows the observations (Figs. 4a and 4b). The fit is noticeable worse for Manning and Darcy-Weisbach DCMs (Figs. 4c and 4d) and as it is showed in Figure 5 these methods are insufficient to reproduce the flow in a vegetated channel in the same manner as Pasche and Mertens methods.

It is important to comment on the relatively poor fit for the Darcy-Weisbach formula (Figs. 2 and 4d). It results from strict bounds on the roughness coefficients, which values were limited to the minimum water depth in the main

b

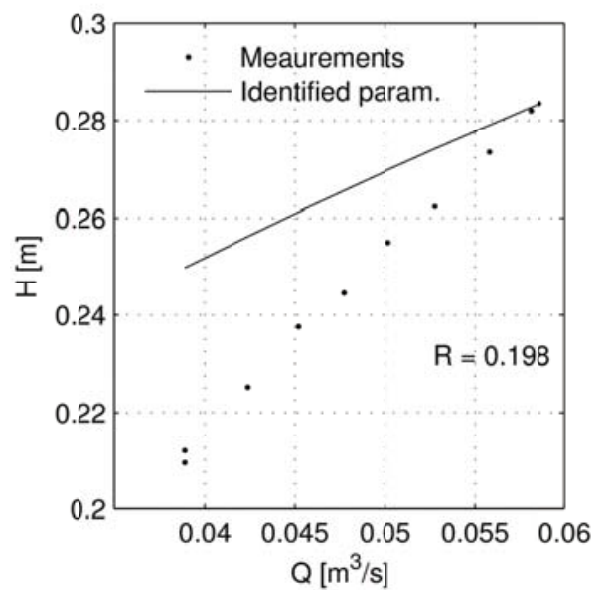

FIGURE 3. Discharge curves obtained with DCM with Manning formula using a model conditioned on a single observation: (a) for lowest discharge value; (b) for highest discharge value 
a

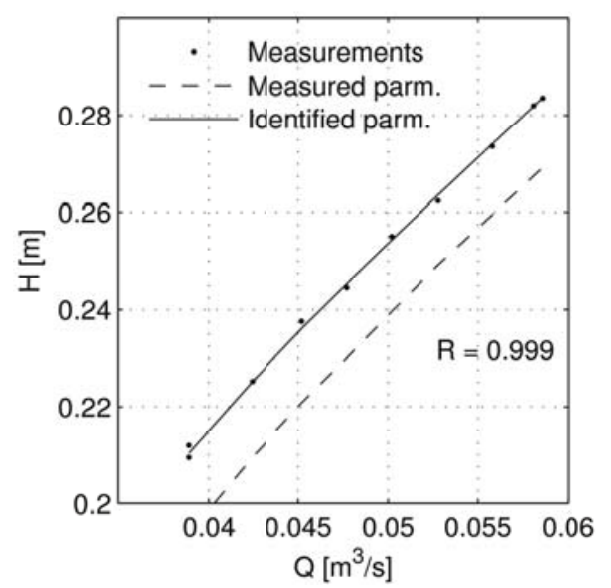

c

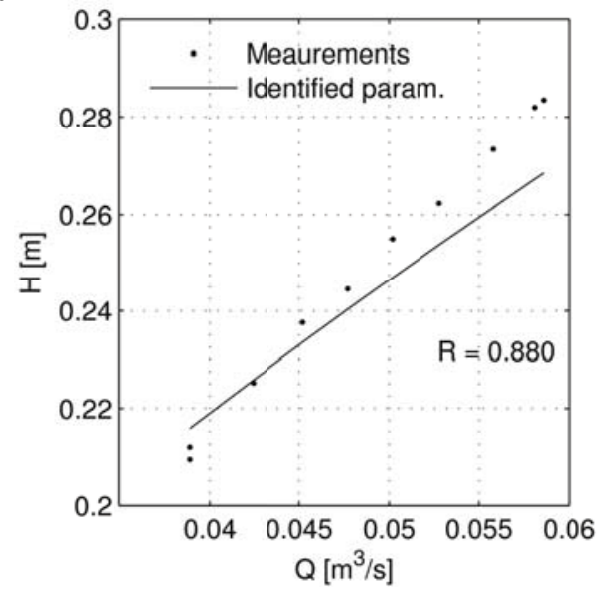

b

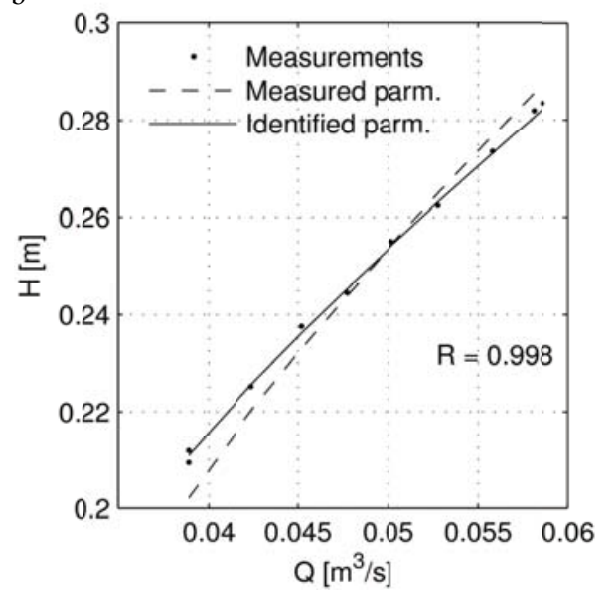

d

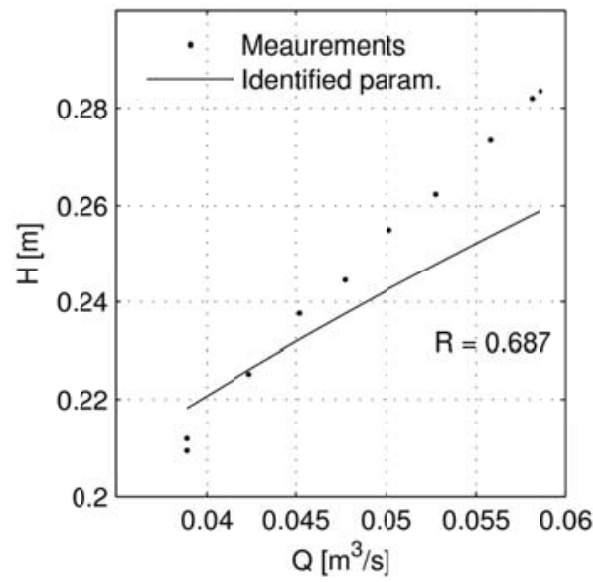

FIGURE 4. Discharge curves identified for "lower bankfull flows" (50\% if observation set): (a) Pasche method; (b) Mertens method; (c) DCM with Manning formula; (d) DCM with Darcy-Weisbach formula

channel(Table 1). Numerical experiments revealed that much better representation (overall $R^{2}>0.9$ ) of water levels can be found beyound this range. It can be easily explained, as the Darcy-Weisbach formula accounts for wall friction and when used to describe resistance caused by vegetation it loses its strigtforward physical interpretation. This is a cause of non-physical values of the roughness height. At this point it can be noted, that the advantage of the Manning formula comes with a much more difficult physical interpretation of its parameters (Manning roughness coefficients).

In Figures 4 and 5 the discharge curves for the Pasche and Mertens methods obtained for identified models (solid lines) are provided along with curves calculated using parameters derived 
a

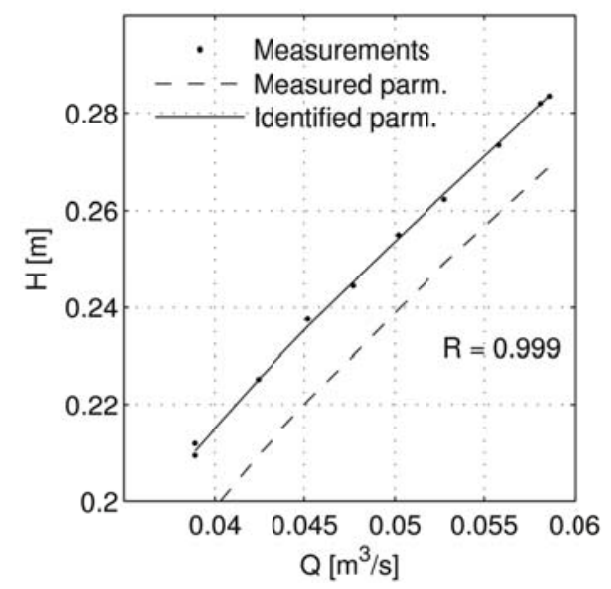

c

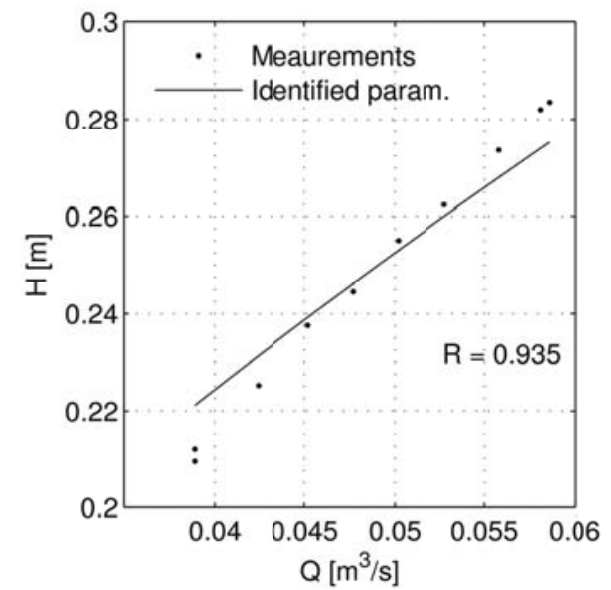

b

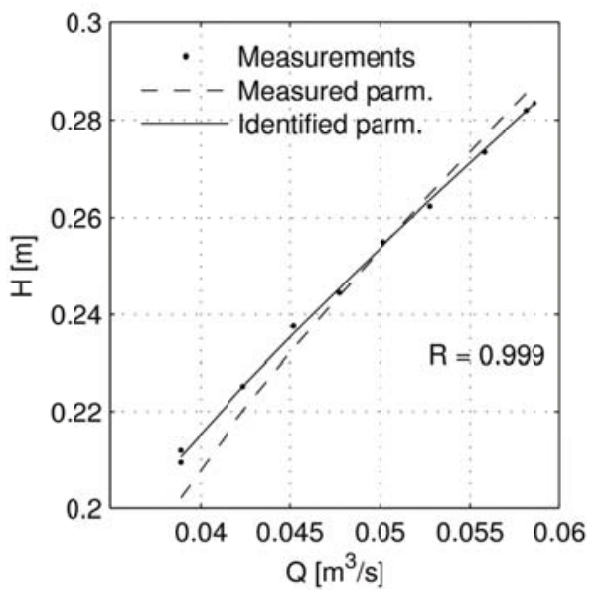

d

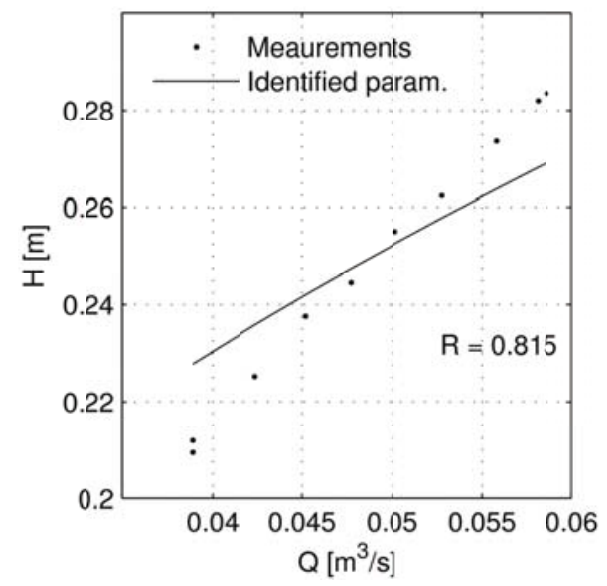

FIGURE 5. Discharge curves identified for full set of observations: (a) Pasche method; (b) Mertens method; (c) DCM with Manning formula; (d) DCM with Darcy-Weisbach formula

from the flume physical properties (dashed lines). The identified parameters allowed for better representation of data. This means however, that the exact physical interpretation of parameters in not maintained. Parameters providing the best model fit have different values than these obtained on the basis of direct measurements. This can be attributed to the imperfect representation of the true process by the model, which however, does not affect the way how the process is reproduced.

Table 2 provides parameter values for Pasche and Mertens methods, obtained on the basis of minimization of Eq. 1 . Results for the $50 \%$ and full observation sets are given all together with real measured values of these parameters. It can be noticed, as it was mentioned 
TABLE 2. Parameter values for Pasche and Mertens methods, obtained as the solution to the inverse problem

\begin{tabular}{|c|c|c|c|c|c|c|}
\hline \multirow[b]{2}{*}{ Parameter } & \multirow[b]{2}{*}{ Unit } & \multirow{2}{*}{$\begin{array}{c}\text { Measured } \\
\text { value }\end{array}$} & \multicolumn{2}{|c|}{ Pasche method } & \multicolumn{2}{|c|}{ Mertens method } \\
\hline & & & $\begin{array}{c}50 \% \text { of lower } \\
\text { observations }\end{array}$ & $\begin{array}{c}\text { Full set of } \\
\text { observations }\end{array}$ & $\begin{array}{c}50 \% \text { of lower } \\
\text { observations }\end{array}$ & $\begin{array}{l}\text { Full set of } \\
\text { observations }\end{array}$ \\
\hline$\hat{a}_{x}$ & $\mathrm{~m}$ & 0.1 & 0.091 & 0.113 & 0.686 & 0.719 \\
\hline$\hat{a}_{y}$ & $\mathrm{~m}$ & 0.1 & 0.704 & 0.293 & 0.131 & 0.193 \\
\hline$\hat{d}_{p}$ & $\mathrm{~m}$ & $8 \cdot 10^{-2}$ & 0.046 & 0.014 & 0.06 & 0.029 \\
\hline$\hat{k}_{f}$ & $\mathrm{~m}$ & $1 \cdot 10^{-2}$ & $1 \cdot 10^{-2}$ & $5 \cdot 10^{-2}$ & $7 \cdot 10^{-2}$ & $7 \cdot 10^{-2}$ \\
\hline$\hat{k}_{c}$ & $\mathrm{~m}$ & $5 \cdot 10^{-2}$ & $2 \cdot 10^{-2}$ & $1 \cdot 10^{-2}$ & $1 \cdot 10^{-2}$ & $1 \cdot 10^{-2}$ \\
\hline$\hat{b}_{I I I} / B_{c}$ & - & - & 0.664 & 0.679 & 0.670 & 0.524 \\
\hline
\end{tabular}

before, that parameters estimated in the inverse problem do not agree with their real physical values. Even more, parameters for these two different observation sets are different, although in both cases the overall coefficient of the determination, calculated for the whole data set is almost $R^{2} \approx 1$. It means that almost perfect representation of the process was obtained for different parameter sets. This finding agrees with a general conclusion of Beven and Binley (1992), who argued that for an overparameterized model of an environmental process, there might be no unique parameter set that provides a satisfactory fit to the observations. It appears that relatively simple models of uniform channel flow, but with a relatively large number of parameters should be considered as overparameterized.

\section{CONCLUSIONS}

The study investigate the applicability of complex methods for the discharge capacity of the compound channel with vegetation, in the case when characteristic of vegetation is unknown. Considering a model input describing plant properties, like spacing, stem diameter, etc. as parameters it was possible to establish these values in terms of the inverse problem. This emphasizes the issues of the required size of the observation data set and the interpretation of the parameter values.

The more complex methods, with more parameters require larger data sets. For the presented simple uniform model, Pasche and Mertens methods required six observation points, while DCM just two. It can be expected, that for more general models (non-uniform and unsteady) this discrepancy in the size of the date set will by much larger. The complex methods are much more accurate, providing for the analyzed flume data almost perfect fit (with $R^{2} \approx 1$ ), where DCM were having noticeable worse fit.

The analysis showed, however, that parameter of complex methods, obtained by minimization of model residuals are not the same as these derived by direct measurements of flume and vegetation properties. This suggests that their physical interpretation is far from being 
perfect, but also that model performance can be significantly improved, when parameters are being identified, rather than measured. On the other hand, the study proves the general conclusion of Beven and Binley (1992) of many possible parameter sets that lead to a sufficient solution. Surprisingly, it applies to the simple models of a uniform channel flow. Therefore, for methods more complex than DCM with Manning formula it seems to be reasonable to apply methods that accounts for such a variation of possible results.

With sufficient observation for identification of model parameters, the more complex methods for the flow in the compound channel with vegetation seems to be an interesting option that allows improving the accuracy of predictions of the water levels. Their parameters can be identified on the basis of an inverse problem, however still several issues should be investigated. For example, it is unclear, what would be the outcome of complex methods, if their parameters were used in the same manner as i.e. Manning coefficients, as "catch all parameters" - outside their physical interpretation. The study shows that for the flume data such a solution might be satisfactory, but it does not apply in real cases.

\section{REFERENCES}

BEVEN K., BINLEY A. 1992: The future of distributed models: model calibration and uncertainty prediction. Hydrol. Proc. 6 (3), 279-298 .

CHOW V.T. 1959: Open-channel hydraulics. McGraw-Hill College.

FREAD D.L. 1989: Flood routing models and the Manning n. In: Channel Flow Resistance: Centennial of Manning Formula, B.C. Yen (Ed.).
Water Resources Publications, Littleton, CO, 421-435.

JALONEN J., JÄRVELÄ J. 2014: Estimation of drag forces caused by natural woody vegetation of different scales. J. Hydrodynam. Ser. B 26 (4), 608-623.

KICZKO A., ROMANOWICZ R.J., OSUCH M., KARAMUZ E. 2013: Maximising the usefulness of flood risk assessment for the River Vistula in Warsaw. Nat. Hazards Earth System Sci. 13 (12), 3443-3455.

KOZIOŁ A.P. 1999: Badania laboratoryjne warunków przepływu w korytach o złożonych przekrojach poprzecznych porośniętych roślinnością wysoką [Experimental studies on flow in channels with compound cross section with vegetation]. PhD thesis WULS-SGGW. Wydawnictwo SGGW, Warszawa.

KOZIOŁ A.P. 2011: Turbulent kinetic energy of water in a compound channel. Ann. Warsaw Univ. Life Sci. - SGGW Land Reclam. 43 (2), 193-205. doi 10.2478/v10060-011-0055-z.

KOZIOŁ A.P. 2013: Three-Dimensional Turbulence Intensity in a Compound Channel. J. Hydraul. Eng. 139 (8), 852-864.

KOZIOŁ A.P., KUBRAK J., KUBRAK E., KRUKOWSKI M., KICZKO A. 2016: Rozkłady prędkości w korycie rzecznym o złożonym przekroju poprzecznym z roślinnością wysoką w terenach zalewowych [Distributions of velocity in compound channels with high vegetation on floodplains]. Acta Sci. Pol. Formatio Circumiectus 15 (4), 227-241.

MERTENS W. 1989: Zur frage hydraulischer Berechnungen naturnaher Fliessgewässer. Wasserwirtschaft 79 (4), 170-179.

NIEDERREITER H. 1992: Random Number Generation and Quasi-Monte Carlo Methods. Society for Industrial and Applied Mathematics, Philadelphia, Pennsylvania.

PASCHE E., ROUVÉ G. 1985: Overbank Flow with Vegetatively Roughened Flood Plains. J. Hydraul. Eng. 111 (9), 1262-1278.

REID D.E., HICKIN E.J. 2008: Flow resistance in steep mountain streams. Earth Surf. Proc. Landforms 33 (14), 2211-2240.

ROMANOWICZ R.J, KICZKO A. 2016: An event simulation approach to the assessment of flood level frequencies: risk maps for the Warsaw reach of the River Vistula. Hydrol. Proc. 30 (14), 2451-2462. 
SHIONO K., KNIGHT D.W. 1991: Turbulent open-channel flows with variable depth across the channel. J. Fluid Mech. 222 (1), 617.

VÄSTILÄ K., JÄRVELÄ J. 2017: Characterizing natural riparian vegetation for modeling of flow and suspended sediment transport. J. Soils Sediment. doi 10.1007/s11368-0171776-3.

VÄSTILÄ K., JÄRVELÄ J., ABERLE J. 2013: Characteristic reference areas for estimating flow resistance of natural foliated vegetation. J. Hydrol. 492, 49-60.

Streszczenie: Identyfikacja parametrów roślinności jako zadanie odwrotne $w$ obliczeniach przepustowości koryt o przekroju złożonym. W ostatnich latach opracowano wiele modeli pozwalających obliczyć przepustowość koryt o przekroju złożonym z roślinnością. Mimo że powstałe procedury są bardzo zaawansowane technicznie, modele hydrauliczne stosowane w praktyce nadal głównie bazują na formule Manninga. Wydaje się, że głównym powodem jest znaczna liczba danych złożonych modeli odnośnie np. charakterystyki szaty roślinnej. W niniejszej pracy pokazano, że odpowiadające zmienne mogą być traktowane jako parametry podlegające standardowej identyfikacji w sensie zagadnienia odwrotnego. Korzystając z wyników badań eksperymentalnych dla koryta dwudziel- nego, zidentyfikowano cztery modele przepływu jednostajnego - złożone (Pasche'ego i Mertensa) oraz stosowane w praktyce równania Manninga i Darcy'ego-Weisbacha wraz z metodą koryta złożonego (MKZ). Badania wykazały, że parametry wszystkich tych procedur mogą być ustalone na drodze minimalizacji residuów, z zastrzeżeniem, że rozmiar wielu wartości obserwowanych jest uzależniony od liczby estymowanych zmiennych. Metody Pasche'ego i Mertensa znacznie lepiej odwzorowały zmierzone głębokości wody niż modele bazujące na równaniach Manninga lub Darcy'ego-Weisbacha. Estymowane wartości parametrów znacznie odbiegają od odpowiadających im wielkościom zmierzonym, niemal są idealne do zastosowania w metodach Pasche'go i Mertensa w celu uzyskania różnych zbiorów parametrów.

\section{MS received December 2017}
Authors' address:
Adam Kiczko
Zakład Hydrauliki
Wydział Budownictwa i Inżynierii Środowiska SGGW
ul. Nowoursynowska 166, 02-787 Warszawa
Poland
e-mail: adam_kiczko@sggw.pl 